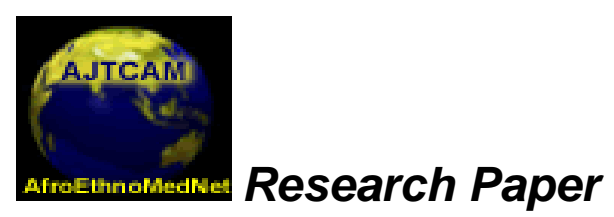

Afr. J. Traditional,

Complementary and Alternative

Medicines

www.africanethnomedicines.net

ISSN 0189-6016@2008

\title{
PROTECTIVE ROLE OF WITHAFERIN-A ON RED BLOOD CELL INTEGRITY DURING 7,12- DIMETHYLBENZ[A]ANTHRACENE INDUCED ORAL CARCINOGENESIS
}

\author{
Shanmugam Manoharan*, Kuppusamy Panjamurthy, Pachaiappan Pugalendi, Subramanian \\ Balakrishnan, Kasinathan Rajalingam, Lakshmanan Vellaichamy, and Linsa Mary Alias \\ ${ }^{1}$ Department of Biochemistry \& Biotechnology, Faculty of Science, \\ Annamalai University, Annamalainagar - 608 002, Tamil Nadu, India.
}

*E-mail: manshisak@yahoo.com

\begin{abstract}
The aim of the present study was to investigate the protective effect of Withaferin-A on red blood cell integrity during 7,12-dimethylbenz[a]anthracene (DMBA) induced oral carcinogenesis. The protective effect of Withaferin-A was assessed by measuring the status of glycoconjugates, membrane bound enzyme activity and red blood cell osmotic fragility. Oral squamous cell carcinoma was induced in the buccal pouch of Syrian golden hamsters by painting with $0.5 \%$ DMBA in liquid paraffin thrice a week for 14 weeks. The levels of glycoconjugates, membrane bound enzyme activity, osmotic fragility and thiobarbituric acid reactive substances (TBARS) were analyzed by using specific colorimetric methods. We observed 100\% tumor formation in DMBA painted hamsters. Increase in plasma glycoconjugates at the expense of red blood cell membrane glycoconjugates levels were observed in DMBA painted hamsters as compared to control hamsters. Erythrocytes from DMBA painted hamsters were more fragile than those from control hamsters. The activity of membrane bound enzyme $\left(\mathrm{Na}^{+} \mathrm{K}^{+}\right.$ATPase $)$decreased whereas TBARS level was increased in DMBA painted hamsters as compared to control hamsters. Oral administration of Withaferin-A at a dose of $20 \mathrm{mg} \mathrm{kg}^{-1}$ bw significantly prevented the tumor formation as well as normalized the biochemical variables in DMBA painted hamsters. Our results thus demonstrate the protective effect of Withaferin-A on red blood cell integrity during DMBA induced oral carcinogenesis.
\end{abstract}

Key words: DMBA, Withaferin-A, Oral cancer, glycoconjugates, osmotic fragility.

Abbreviations: DMBA - 7,12-dimethylbenz[a]anthracene TBARS - thiobarbituric acid reactive substances

\section{Introduction}

Carcinogenesis is a multi-step process involving several mutations, each of which results in discrete changes in the cellular metabolism (Ranajit, 2004). Oral squamous cell carcinoma is predominantly a disease of human population in the fifth to eighth decades of life. The incidence and mortality rate of oral cancer vary widely across the world. However, the higher incidences of oral cancer are reported every year from developing countries, particularly from India (Moore et al., 2000). Epidemiological studies have shown that chewing of betel quid with tobacco is the major etiological factor of oral carcinogenesis in India (Gupta and Nandakumar; 1999).

The importance of tumor markers for the detection of malignancies and its prognosis has prompted the investigation of the possible biochemical markers of several malignancies. DMBA-induced experimental oral cancer is the most widely-accepted experimental model for studying chemoprevention of oral cancer, since it has several morphological and histological similarities with human oral carcinoma (Miyata et al., 2001; Shklar, 1999). 
Neoplastic transformation of a variety of cell types is associated with changes in the composition of membrane glycoproteins (Dwivedi et al., 1990). Glycoproteins are complex proteins in which carbohydrates are linked covalently to asparagine or serine or threonine residues of polypeptides. The cell surface glycoproteins have been shown to play an important role in pinocytosis, differentiation, tumorigenesis, intracellular recognition and adhesion, as receptors for many hormones and viruses and as mediators of immunological specificity. Tumorassociated carbohydrate changes have also been used in the diagnosis of human cancers (Dabelsteen, 1996). Measurement of serum glycoconjugates is useful in the diagnosis of patients with oral pre-cancer or cancer (Manoharan et al, 2004).

Sialic acid, a group of acylated neuraminic acid, plays a major role in the antigenic characterization of cells. They are widely distributed in nature as terminal sugars on oligosaccharides attached to protein or lipid moieties. Sialic acid molecules can potentially inhibit intermolecular and intercellular interaction by virtue of their negative charge. Serum sialic acid levels have been used as laboratory markers in cancers (Goodarzi et al, 2005; Sebzda et al, 2006). It has also been demonstrated that metastatic potential of tumor cells is proportional to cell surface sialylation (Varki, 1997). Marked elevation of serum sialic acid concentrations with various clinical stages of a disease has been documented in several malignancies including oral cancer (Manoharan et al., 2008 and Aranganathan et al., 2005). Serum fucose, a terminal pentose sugar of the glycoprotein chains, is detectable in the blood of both normal persons and persons with different types of malignancies. Profound studies have shown an increased serum fucose level in a wide spectrum of malignancies (Vasanthi et al, 1998 ; Rao et al., 1998; Escrevente et al., 2006). Fucose and mannose are the most essential sugars when it comes to slowing the growth of cancer cells (Rao et al., 1998).

$\mathrm{Na}^{+} / \mathrm{K}^{+}$-ATPase is ubiquitously distributed throughout cells of higher organisms and its importance is highlighted by the fact it represents the only mechanism for $\mathrm{Na}^{+}$extrusion in mammalian cells. The $\mathrm{Na}^{+} / \mathrm{K}^{+}$-ATPase ( $\mathrm{Na}^{+} / \mathrm{K}^{+}$-pump) maintains the electro-chemical gradients of $\mathrm{Na}^{+}$and $\mathrm{K}^{+}$by catalyzing the transfer of three intracellular $\mathrm{Na}^{+}$ions in exchange for two extracellular $\mathrm{K}^{+}$ions per molecule of ATP hydrolyzed (Thirunavukkarasu and Sakthisekaran, 2003). The activities of red blood cell membrane bound enzymes are affected during elevated membrane lipid peroxidation and during alterations in blood red cell osmotic fragility (Rauchova et al., 1995; Rajalingam et al, 2008).

Withania somnifera (Solanaceae), a shrub commonly found on the Indian subcontinent, has been used for centuries as a traditional medicine for various human ailments. Experimental studies have reported that Withania somnifera have antitumor and immunomodulatory activities (Davis and Kuttan, 2001; Davis and Kuttan, 2000). Withaferin-A, a highly oxygenated steroidal lactone, is the principal withanolide in Indian Withania somnifera and its related Solanaceae species. Diverse pharmacological activities reported for Withaferin-A includes antiinflammatory, antitumor and antioxidant properties (Sharada et al., 1996; Bhattacharya et al., 1997). The structure of Withaferin-A is given in Figure 1.

To the best of our knowledge, we have found no scientific reports on the protective effect of Withaferin-A on red blood cell integrity during 7,12-dimethylbenz[a]anthracene induced hamster buccal pouch carcinogenesis. The present study thus investigated the protective effect of Withferin-A on red blood cell integrity during DMBA induced oral carcinogenesis.

\section{Materials and Methods Animals}

Male golden Syrian hamsters 8-10 weeks old weighing 80-120g was purchased from National Institute of Nutrition, Hyderabad, India and was maintained in Central Animal House, Rajah Muthaiah Medical College and Hospital, Annamalai University. The hamsters were housed five in a polypropylene cage and provided standard pellet diet and water ad libitum. The hamsters were maintained under controlled conditions of temperature and humidity with a $12 \mathrm{~h}$ light/dark cycle. The hamsters were maintained as per the principles and guidelines of the ethical committee for animal care of Annamalai University in accordance with Indian National Law on animal care and use.

\section{Chemicals}

The carcinogen, DMBA, was obtained from Sigma-Aldrich Chemical Pvt. Ltd., Bangalore India. All other chemicals used were of analytical grade. 


\section{Isolation of Withaferin-A from Withania somnifera root}

Withaferin-A (WA) was extracted and isolated from commercially available Withania somnifera root powder by the method of Subramanian and Sethi (1969). The crude extract was prepared with 95\% ethanol and further fractionation was carried out using petroleum ether, ether and chloroform, in that order. The ether and chloroform fractions were subjected to column chromatography (neutral alumina) and thin layer chromatography (silica gel). The final product, Wihaferin-A, a steroidal lactone $(4 \beta, 27$ dihydroxy-1-oxo-5 $\beta, 6 \beta$, epoxy witha $2-24$ dienolide) obtained as a creamy white crystalline substance, has $\mathrm{Rf}=0.4$ and molecular weight 470 . The identity of isolated Withaferin-A was done by Mass spectra and its identity was confirmed by comparing with the authentic Withaferin-A, purchased from Calbiochem, Darmstadt, Germany. The yield and purity of the isolated Withaferin-A was found to be $0.11 \%$ and $>90 \%$ respectively. For experimental studies, the obtained Withaferin-A is first dissolved in a few drops of absolute ethanol followed by dilution with 30\% polyethylene glycol-400 (PEG-400) in phosphate-buffered saline (PBS).

\section{Experimental design}

The experimental design (Proposal No. 357 dated. 18.10.2006) was approved by the Annamalai University animal ethical committee (Register number 160/1999/CPCSFA), Annamalai University, Annamalainagar. A total number of 40 hamsters were randomized into four groups of 10 hamsters each. Group 1 hamsters were served as control and were painted with liquid paraffin alone thrice a week for 14 weeks on their left buccal pouches. Groups 2 and 3 hamsters were painted with $0.5 \%$ DMBA in liquid paraffin thrice a week for 14 weeks on their left buccal pouches. DMBA painting in hamster's buccal pouches was done by using number 4 painting brush, which leaves approximately $0.4 \mathrm{mg}$ DMBA on hamster buccal pouch in each application (Shklar, 1999). Group 2 hamsters received no other treatment. Group 3 hamsters were orally administered Withaferin-A at a dose of $20 \mathrm{mg} / \mathrm{kg}$ bw, starting one week before the exposure to the carcinogen and continued on days alternate to DMBA painting, until the sacrification of the hamsters. Group 4 hamsters received oral administration of Withaferin-A alone throughout the experimental period. The experiment was terminated at the end of 15 weeks and all hamsters were sacrificed by cervical dislocation.

\section{Biochemical analysis}

Biochemical studies were conducted on plasma and erythrocyte membrane of control and experimental hamsters in each group. Blood samples were collected into heparinized tubes. The plasma was separated by centrifugation at 3000rpm for 15 mins. After plasma separation, the erythrocyte membrane was prepared by the method of Dodge et al., (1968) modified by Quist (1980). Lipid peroxidation as evidenced by the formation of thiobarbutiric acid reactive substances (TBARS) in erythrocyte membrane was estimated by the method of Donnan (1950). The precipitate obtained after treating the plasma with 95\% ethanol was used for the estimation of protein bound hexose and hexosamine. Similarly, the precipitate obtained after treating the erythrocyte membranes with $1 \%$ phosphotungstic acid followed by 5\% TCA was used for the estimation of protein found hexose and hexosamine. The protein bound hexose, hexosamine, total sialic acid and fucose were estimated by the methods of Niebes , 1972), Wagner (1979), Warren (1959) and Dische and Shettles (1948) respectively. Plasma lipid bound sialic acid level was determined by the method of Katopodis and Stock (1980). Osmotic fragility was determined by the method of Parpart et al. (1946) and mean corpuscular fragility was calculated by recording the saline concentration, which would have resulted in $50 \%$ haemolysis.

\section{Statistical Analysis}

The data are expressed as mean \pm SD. Statistical comparisons were performed by One-way analysis of variance (ANOVA), followed by Duncan's Multiple Range Test (DMRT). The results were considered statistically significant if the $\mathrm{p}$ values were less than 0.05 .

\section{Results}

The levels of protein bound hexose, hexosamine, total sialic acid, lipid bound sialic acid and fucose in plasma of control and experimental hamsters in each group is shown in Table 1. The levels of plasma protein bound 
Table 1: Protein bound hexose, hexosamine, total sialic acid, lipid bound sialic acid and fucose in plasma of control and experimental hamsters in each group $(n=10)$

\begin{tabular}{|c|c|c|c|c|c|}
\hline $\begin{array}{c}\text { Parameters } \\
\text { Groups }\end{array}$ & $\begin{array}{c}\text { Protein bound } \\
\text { hexose }(\mathrm{mg} / \mathrm{dL})\end{array}$ & $\begin{array}{l}\text { Protein bound } \\
\text { hexosamine } \\
(\mathrm{mg} / \mathrm{dL})\end{array}$ & $\begin{array}{c}\text { Total Sialic acid } \\
(\mathrm{mg} / \mathrm{dL})\end{array}$ & $\begin{array}{l}\text { Lipid bound } \\
\text { sialic acid } \\
(\mathrm{mg} / \mathrm{dL})\end{array}$ & Fucose (mg/dL) \\
\hline $\begin{array}{l}\text { Group I } \\
\text { Control }\end{array}$ & $92.10 \pm 8.24^{\mathrm{a}}$ & $78.24 \pm 6.10^{\mathrm{a}}$ & $50.14 \pm 4.10^{\mathrm{a}}$ & $14.18 \pm 1.20^{\mathrm{a}}$ & $9.38 \pm 0.52^{\mathrm{a}}$ \\
\hline $\begin{array}{l}\text { Group II } \\
\text { DMBA }\end{array}$ & $135.30 \pm 14.68^{b}$ & $110.82 \pm 9.26^{b}$ & $79.40 \pm 6.28^{b}$ & $32.24 \pm 2.72^{b}$ & $18.23 \pm 1.10^{\mathrm{b}}$ \\
\hline $\begin{array}{c}\text { Group III } \\
\text { DMBA + } \\
\text { Withaferin-A }\end{array}$ & $100.34 \pm 7.65^{c}$ & $85.26 \pm 7.05^{c}$ & $54.85 \pm 5.28^{c}$ & $16.25 \pm 2.20^{c}$ & $10.26 \pm 0.92^{c}$ \\
\hline $\begin{array}{c}\text { Group IV } \\
\text { Withaferin-A }\end{array}$ & $90.12 \pm 9.30^{\mathrm{a}}$ & $77.53 \pm 7.68^{\mathrm{a}}$ & $49.43 \pm 3.86^{\mathrm{a}}$ & $13.44 \pm 0.98^{\mathrm{a}}$ & $9.30 \pm 0.65^{\mathrm{a}}$ \\
\hline
\end{tabular}

Values are expressed as mean \pm SD.

Values not sharing a common superscript significantly differ at $\mathrm{P}<0.05$ (DMRT).

Table 2: Protein bound hexose, hexosamine, total sialic acid levels in erythrocyte membranes of control and experimental hamsters in each group $(n=10)$

\begin{tabular}{|c|c|c|c|}
\hline \begin{tabular}{c} 
Parameters \\
\hdashline Groups
\end{tabular} & $\begin{array}{l}\text { Protein bound hexose } \\
(\mu \mathrm{g} / \mathrm{mg} \text { protein })\end{array}$ & $\begin{array}{c}\text { Protein bound hexosamine } \\
\text { ( } \mu \mathrm{g} / \mathrm{mg} \text { protein) }\end{array}$ & $\begin{array}{l}\text { Total Sialic acid } \\
\text { ( } \mu \mathrm{g} / \mathrm{mg} \text { protein) }\end{array}$ \\
\hline $\begin{array}{l}\text { Group I } \\
\text { Control }\end{array}$ & $132.85 \pm 10.68^{\mathrm{a}}$ & $87.42 \pm 6.83^{\mathrm{a}}$ & $36.56 \pm 3.41^{\mathrm{a}}$ \\
\hline $\begin{array}{l}\text { GroupII } \\
\text { DMBA }\end{array}$ & $97.20 \pm 7.87^{b}$ & $65.27 \pm 5.94^{b}$ & $24.18 \pm 2.62^{b}$ \\
\hline $\begin{array}{c}\text { GroupIII } \\
\text { DMBA + } \\
\text { Withaferin-A }\end{array}$ & $122.68 \pm 9.74^{\mathrm{c}}$ & $79.66 \pm 7.67^{c}$ & $32.67 \pm 3.22^{c}$ \\
\hline $\begin{array}{c}\text { GroupIV } \\
\text { Withaferin-A }\end{array}$ & $135.15 \pm 12.62^{\mathrm{a}}$ & $87.62 \pm 6.53^{\mathrm{a}}$ & $36.75 \pm 3.68^{\mathrm{a}}$ \\
\hline
\end{tabular}

Values are expressed as mean $\pm \mathrm{SD}$.

Values not sharing a common superscript significantly differ at $\mathrm{P}<0.05$ (DMRT) 


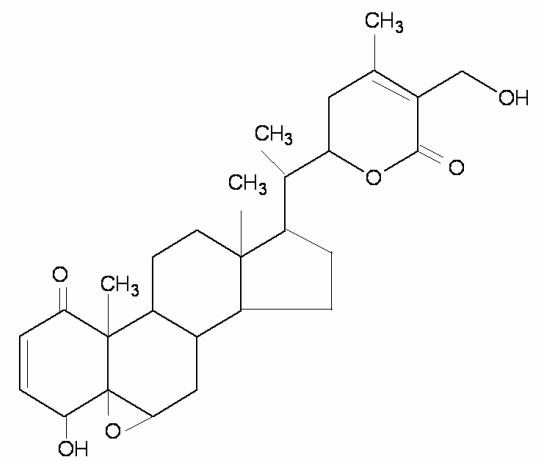

Figure 1: Structure of Withaferin-A

Table 3: TBARS content and activity of $\mathrm{Na}^{+}-\mathrm{K}^{+}$ATPase, in erythrocyte membrane and Mean corpuscular fragility of control and experiments hamsters in each group $(n=10)$.

\begin{tabular}{|c|c|c|c|}
\hline Parameters & $\begin{array}{c}\text { Erythrocyte membrane TBARS (n } \\
\text { moles/mg protein) }\end{array}$ & $\begin{array}{c}\mathbf{N a}^{+}-\mathbf{K}^{+} \mathbf{A T P a s e}\left(\mathbf{U}^{\mathrm{A}} / \mathbf{m g}\right. \\
\text { protein) }\end{array}$ & $\begin{array}{c}\text { Mean corpuscular } \\
\text { fragility* }^{*}\end{array}$ \\
\hline Groups & $0.34 \pm 0.07^{\mathrm{a}}$ & $1.08 \pm 0.09^{\mathrm{a}}$ & $0.40 \pm 0.02^{\mathrm{a}}$ \\
\hline $\begin{array}{c}\text { Group I } \\
\text { Control }\end{array}$ & $1.10 \pm 0.12^{\mathrm{b}}$ & $0.76 \pm 0.08^{\mathrm{b}}$ & $0.64 \pm 0.05^{\mathrm{b}}$ \\
\hline $\begin{array}{c}\text { Group II } \\
\text { DMBA }\end{array}$ & $0.42 \pm 0.09^{\mathrm{c}}$ & & \\
\hline $\begin{array}{c}\text { Group III } \\
\text { DMBA + } \\
\text { Withaferin-A }\end{array}$ & $0.32 \pm 0.08^{\mathrm{a}}$ & $0.97 \pm 0.09^{\mathrm{c}}$ & $0.48 \pm 0.04^{\mathrm{c}}$ \\
\hline $\begin{array}{c}\text { Group IV } \\
\text { Withaferin-A }\end{array}$ & & $1.05 \pm 0.07^{\mathrm{a}}$ & $0.39 \pm 0.02^{\mathrm{a}}$ \\
\hline
\end{tabular}

A - $\mu$ mole of inorganic phosphorus liberated/hour. Values are expressed as mean \pm SD. Values not sharing a common superscript significantly differ at $\mathrm{P}<0.05$ (DMRT). * Concentration of $\mathrm{NaCl}$ solution ( $\mathrm{g} \%$ ) at $\mathbf{5 0 \%}$ hemolysis. 


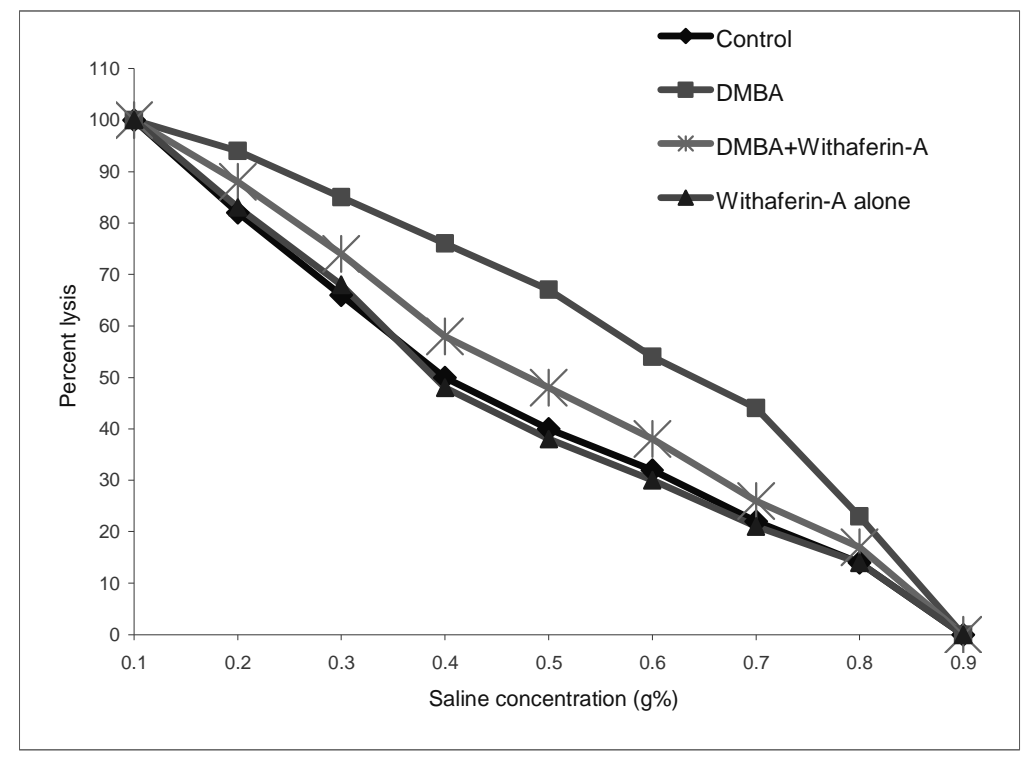

Figure 2: Osmotic fragility curve of control and experimental hamsters in each group. The degree of haemolysis was calculated by comparing with $0.1 \% \mathrm{NaCl}$ solution which represented $100 \%$ lysis.

hexose, hexosamine, total sialic acid, lipid bound sialic acid and fucose were significantly increased in tumor bearing hamsters as compared to control hamsters. Oral administration of Withaferin-A at a dose of $20 \mathrm{mg} / \mathrm{kg}$ body weight to DMBA painted harmsters brought back the levels to near normal range. Hamsters treated with WithaferinA alone showed no significant difference in protein bound hexose, hexosamine, total sialic acid, lipid bound sialic acid and fucose levels as compared to control hamsters.

The levels of protein bound hexose, hexosamine, and total sialic acid, in erythrocyte membrane of control and experimental hamsters in each group is shown in Table 2. The levels of protein bound hexose, hexosamine, and total sialic acid were significantly decreased in erythrocyte membranes of tumor bearing hamsters as compared to control hamsters. Oral administration of Withaferin-A at a dose of $20 \mathrm{mg} / \mathrm{kg}$ body weight to DMBA painted harmsters brought back the status to near normal range. Hamsters treated with Withaferin-A alone showed no significant difference in protein bound hexose, hexosamine, and total sialic acid levels as compared to control hamsters.

The levels of erythrocyte membrane TBARS, activity of membrane bound $\mathrm{Na}^{+} \mathrm{K}^{+}$-ATPase and red blood cell mean corpuscular fragility in control and experimental hamsters in each group are shown in Table 3 . The activity of membrane bound $\mathrm{Na}^{+} \mathrm{K}^{+}$-ATPase was significantly decreased whereas TBARS levels and mean corpuscular fragility were increased in red blood cell of tumor bearing hamsters as compared to control hamsters. The activity of $\mathrm{Na}^{+} \mathrm{K}^{+}$-ATPase, TBARS and mean corpuscular fragility levels were brought back to near normal range in DMBA-painted hamsters treated with Withaferin-A. No significant difference was observed in hamsters treated with Withaferin-A alone and control hamsters.

Osmotic fragility curves for control and experimental hamsters in each group are shown in Figure 2. The fragility curve of DMBA painted hamsters was shifted to the right for control hamsters. Treatment of DMBA painted hamsters with Withaferin-A shifted the curve to the left of tumor bearing hamsters. Mean corpuscular fragility values did not differ significantly in hamsters treated with Withaferin-A alone as compared to control hamsters. 


\section{Discussion}

Cell surface glycoproteins and glycolipids of tumor cells have altered carbohydrate composition that may contribute to aberrant cell-cell recognition, cell adhesion, antigenicity and invasiveness characteristics of malignant cells (Dabelsteen, 1996). Cell surface glycosyl residues play an important role in regulating cell proliferation and epithelial growth (Aranganathan et al., 2005). In the present study, increased levels of plasma glycoconjugates at the expense of erythrocyte membranes were noticed. A loss in epithelial cell surface carbohydrate during experimental oral carcinogenesis has been reported (Dabelsteen, 1996). The depletion of erythrocyte membrane glycoproteins seen in the present study may be due to increased degradation or decreased synthesis or as a result of increased shedding into circulation. Increase in plasma glycoconjugates levels could therefore be due to the release of glycoproteins from the erythrocyte membrane or tumor tissues itself. Neoplastic transformation leads to elevated plasma sialic acid concentration through the shedding or secretion of sialic acid from the tumor cell surfaces (Senthil et al, 2007; Suresh et al, 2007). Studies have shown that malignant changes are accompanied by increased expression of membrane associated fucose containing macromolecules (Kim et al, 1982; Rao et al., 1998). Tumor itself may contribute to circulating fucose concentrations either by spontaneous release of glycoproteins as the mass grows or as a result of cell damage through host attack or treatment (Glick, 1978). Oral administration of WithferinA to DMBA painted animals protected the integrity of red blood cell membrane by maintaining the status of glycoconjugates during oral carcinogenesis.

In the present study, erythrocyte membrane $\left(\mathrm{Na}^{+} / \mathrm{K}^{+}\right.$-ATPase) activity was decreased accompanied by decrease in sodium and increase in potassium levels in plasma of tumor bearing hamsters. Oxidative stress in the system alters the activities of membrane bound enzymes, which is assumed to be crucial for cell lysis (Thirunavukarasu and Sakthisekaran, 2003). It has been reported that alterations in red cell fragility can cause change in $\mathrm{Na}^{+} / \mathrm{K}^{+}$-ATPase activity (Selvendiran and Sakthisekaran, 2004). Lowered activity of erythrocyte membrane $\mathrm{Na}^{+} / \mathrm{K}^{+}$-ATPase in oral cancer bearing hamsters is probably due to increased membrane lipidperoxidation. Red blood cells obtained from tumor bearing hamsters were found to be more fragile than those obtained from control hamsters. Increased red cell osmotic fragility is probably due to their altered lipid content and increased oxidative stress. Our study suggests that the membrane permeability and cellular homeostasis are severely disturbed during DMBA-induced oral carcinogenesis. Oral administration of Withaferin-A significantly restored levels of membrane TBARS, activity of $\mathrm{Na}^{+} / \mathrm{K}^{+}$-ATPase and red cell osmotic fragility. Our results indicate that Withaferin-A maintained the structural integrity of the membrane and prevented the membrane abnormalities during oral carcinogenesis.

\section{Conclusion}

The present study concludes that Withaferin-A protected red blood cell integrity during DMBA induced oral carcinogenesis by maintaining the status of membrane glycoconjugates, $\mathrm{Na}^{+} / \mathrm{K}^{+}$-ATPase activity and red blood cell osmotic fragility.

\section{Acknowledgements}

Financial support from Indian Council of Medical Research (ICMR), New Delhi to Mr. K. Panjamurthy, in the form of Senior Research Fellowship (SRF) is gratefully acknowledged.

\section{References}

1. Aranganathan, S., Senthil, K. and Nalini, N. (2005). A case control study of glycoprotein status in ovarian carcinoma. Clin. Biochem. 38: 535-539.

2. Bhattacharya, S.K., Satyan, K.S. and Ghosal, S. (1997). Antioxidant activity of glycowithanolides from Withania somnifera. Indian J Exp Biol. 35: 236-39.

3. Dabelsteen, E. (1996). Cell surface carbohydrates as prognostic markers in human carcinomas. J. Pathol., 179: $358-369$.

4. Davis, L. and Kuttan, G. (2000). Immunomodulatory activity of Withania somnifera. J Ethnopharmacol. 71: 193-200. 
5. Davis, L. and Kuttan, G. (2001). Effects of Withania somnifera on DMBA induced carcinogenesis. J Ethanopharmacol. 75: 165-168.

6. Dische, L. and Shettles, L.B. (1948). Specific color reactions of methyl pentoses and spectrophotometric micromethod for their determination. J Biol Chem. 175: 595-604.

7. Dodge J.F., Michell, G. and Hanahan, D.J. (1968). The preparation of hemoglobin free ghosts of human red blood cells. Arch Biochem Biophys. 110: 119-130.

8. Donnan, S.K. (1950). The thioharbituric acid test applied to tissues from rats treated in various ways. J Biol Chem. 182: 415-419.

9. Dwivedi, C., Dixit, M. and Hardy, R.E. (1990). Plasma lipid-bound sialic acid alterations in neoplastic diseases. Experientia. 46: 91-97.

10. Escrevente, C., Machado, C., Brito, C., Reis, C.A., Stoeck, A., Runz, S., Marme, A., Altevogt P. and Costa J. (2006). Different expression levels of alpha $3 / 4$ fucosyltransferases and Lewis determinants in ovarian carcinoma tissues and cell lines. Int. J. Oncol. 29: 557-566.

11. Glick, M.C. (1978). Fucosylation- A role in cell function. In: Walborg EF, ed. Glycoproteins and glycolipids in disease processes. Washington DC: American Clinical Society. 405-411.

12. Goodarzi, M.T., Shafiel, M., Nomani, H. and Shahriarahmadi, A. (2005). Relationship between total and lipid bound serum sialic acid and some tumor markers. Iran J. Med. Sci. 30: 124-127.

13. Gupta, P.C. and Nandakumar (1999). Oral cancer scene in India. Oral Dis. 5: 1-2.

14. Katopodis, N.N. and Stock, C.C. (1980). Improved method to determine lipid bound sialic acid in plasma. Res Commun Chem Pathol Pharmacol. 30: 171-180.

15. Kim, Y.S., Kim, Y.W., Siddiqui, B. and Tsao, D. (1982). Membrane-associated fucose-containing glycoproteins and glycolipids of cultured epithelial cells from human colonic adenocarcinoma and fetal intestine. Eur J Cancer Clin Oncol. 18: 1329-1336.

16. Manoharan, S., Kavitha, K., Balakrishnan, S. and Rajalingam, K. (2008). Clerodendron inerme protects cellular integrity during 7,12-dimethylbenz[a]-anthracene-induced hamster buccal pouch carcinogenesis. Afr. J. Trad. CAM. 5: 213-222.

17. Manoharan, S., Padmanabhan, M., Kolanjiappan, K., Ramachandran, C.R. and Suresh, K. (2004). Analysis of glycoconjugates in patients with oral squamous cell carcinoma. Clin. Chim. Acta., 339: 91-96.

18. Miyata, M., Furukawa, M., Takahasi, K., Gonzalez, F.J. and Yamazoe, Y. (2001). Mechanism of 7,12dimethylbenz(a)anthracene induced immunotoxicity: Role of metabolic activation at the target organ. Jpn J Pharmacol. 86: 302-309.

19. Moore, S.R., Johnson, N.W., Pierce, A.M., Wilson, D.F. (2000). The epidemiology of mouth cancer: A review of global incidence. Oral Dis. 6: 65-74.

20. Niebes, P. (1972). Determination of enzymes and degradation product of glycosaminoglycan metabolism in the serum of health and various subjects. Clin Chim Acta. 42: 399-408.

21. Parpart, A.K., Lorene, P.B., Parpart, E.R., Gragg, J.R. and Chase, A.M. (1946). The osmotic resistance (fragility) of human red blood cells. J Clin Invest. 26: 636-640.

22. Quist, E.E. (1980). Regulation of erythrocyte membrane shape by $\mathrm{Ca}^{2+}$. Biochem Biophys Res Commun. 92: 631-637.

23. Rajalingam, K., Renju, G.L., Balakrishnan, S. and Manoharan, S. (2008). Effect of Clerodendron inerme on erythrocyte membrane integrity during 7,12-dimethylbenz[a]anthracene induced skin carcinogenesis in Swiss albino mice. Asian J Sci Res. 1: 246-255.

24. Ranajit, S. (2004). Principles and management of cancer. In: A practical guide. B.I. Publication Pvt. Ltd., New Delhi., pp1-3.

25. Rao, V.R., Krishnamoorthy, L., Kumaraswamy, S.V. and Ramaswamy, G. (1998). Circulating levels in serum of total sialic acid, lipid-associated sialic acid and fucose in precancerous lesions and cancer of the oral cavity. Cancer Detect Prev. 22: 237-240.

26. Rauchova, H., Ledvinkova, J., Kalous, M. and Drahota, Z. (1995). The effect of lipidperoxidation on the activity of various membrane-bound ATPases in rat kidney. Int J Biochem Cell Biol. 27: 251-255.

27. Sebzda, T., Saleh, Y., Gburek, J., Warwas, M., Andrzejak, R., Siewinski, M. and Rudnicki, J. (2006). Total and lipid-bound plasma sialic acid as diagnostic markers in colorectal cancer patients: correlation with cathepsin B expression in progression to Dukes stage. J. Exp. Ther. Oncol. 5: 223-229.

28. Selvendiran, K. and Sakthisekaran, D. (2004). Chemopreventive effect of piperine on modulating lipid peroxidation and membrane bound enzymes in benzo(a)pyrene induced lung carcinogenesis. Biomed. Pharmacother. 58: 264-267. 
29. Senthil, N., Manoharan, S., Balakrishnan, S., Ramachandran, C.R., Muralinaidu, R. and Rajalingam, K. (2007). Modifying effects of Piper longum on cell surface abnormalities in 7,12-dimethylbenz[a]anthracene induced hamster buccal pouch carcinogenesis. Int. J. Pharmacol. 3: 290-294.

30. Sharada, A.C., Solomon, F.E., Devi, P.U., Udupa, N. and Srinivasan, K.K. (1996). Antitumor and radiosensitizing effects of Withaferin-A on mouse Ehrlich ascites carcinoma in vivo. Acta Oncol. 35: 95100.

31. Shklar, G. (1999). Development of experimental oral carcinogenesis and its impact on current oral cancer research. J Dent Res. 78: 1768-1772.

32. Subramanian, S.S. and Sethi, P.D. (1969). Withaferin-A from Withania somnifera coagulants roots, Current. Science. (India), 38: 267-268.

33. Suresh, K., Manoharan, S., Panjamurthy, K. and Senthil, N. (2007). Modifying effects of Annona squamosa on glycoconjugates levels in 7,12-dimethylbenz(a)anthracene induced hamster buccal pouch carcinogenesis. J Med Sci., 7: 100-105.

34. Thirunavukarasu, C. and Sakthisekaran, D. (2003). Influence of sodium selenite on glycoprotein contents in normal and N-nitrosodiethylamine initiated and phenobarbital promoted rat liver tumors. Pharmacol. Res. 48: $167-171$.

35. Varki, A. (1997). Sialic acids as ligands in recognition phenomena. FASEB J. 11: 248-255.

36. Vasanthi, R., Rao, L.K., Kumarasamy, S.V. and Ramaswamy, G. (1998). Circulating levels in serum of total sialic acid, lipid associated sialic acid and fucose in precancerous lesions and cancer of the oral cavity. Cancer Detect. Prev. 22: 237-240.

37. Wagner, W.D. (1979). A more sensitive assay discriminating galactosamine and glucosamine in mixture. Anal Biochem. 94: 369-394.

38. Warren, L. (1959). Thiobarbituric acid and assay of sialic acid. J Biol Chem. 30: 171-180. 